\title{
The Effect of Age on the Properties of Poly(A)-containing Messenger RNA in Physarum polycephalum
}

\author{
By ALISTAIR J. P. BROWN $†$ AND NORMAN HARDMAN* \\ Department of Biochemistry, Marischal College, University of Aberdeen, Aberdeen AB9 IAS
}

(Received 25 June 1980)

\begin{abstract}
The effect of ageing on the properties of polysomal poly(A)-containing messenger RNA [poly(A)+ mRNA] of Physarum polycephalum has been investigated. Using poly(U)Sepharose affinity chromatography it was shown that shortening of the poly(A) tract occurred as the age of the mRNA population increased. Analysis of the poly(A) segments by use of polyacrylamide gel electrophoresis, after digestion of polysomal poly(A)+ mRNA molecules with RNAase A and RNAase T1, revealed that their lengths ranged from 140 to 220 nucleotide residues. A reduction in the efficiency of utilization of mRNA for translation as the age of the mRNA population increased was demonstrated by measuring the proportion of poly(A)+ mRNA present in the polysomal fraction as compared with post-polysomal material.
\end{abstract}

\section{INTRODUCTION}

Physarum polycephalum is an attractive organism for studies of the control of gene expression for a number of reasons. For example, synchronous nuclear division occurs during growth in Physarum plasmodia, affording an opportunity to study expression during the cell cycle without the requirement for artificial methods of cell synchronization. Also, several stages of differentiation exist during the life-cycle of Physarum, a property that has led to extensive use of this organism as a model system for studies of differential gene expression (Dee, 1975). Despite these advantages, limited progress has been made so far with investigation of the properties of mRNA in Physarum. This is, in part, due to technical problems related to the high endogenous levels of ribonuclease present in the organism. The conflicting reports concerning the length of the $3^{\prime}$ poly(A) tract in Physarum mRNA may be another manifestation of these problems; the poly(A) segments derived from poly(A)containing mRNA [poly(A)+ mRNA] were reported to be in the range 100 to 250 nucleotides by Fouquet et al. (1974), whereas Adams \& Jeffery (1978) estimate the average length to be 65 nucleotides. In the present study an attempt was made to determine the length of poly(A) tracts in Physarum mRNA under conditions which minimize artefactual degradation by ribonuclease, and with reference to appropriate RNA size standards.

A comparison of the relative lengths of poly(A) segments in different RNA populations was achieved by thermal elution of poly (A)+ mRNA from poly(U)-Sepharose. This provides an alternative to estimating the size of the poly(A) tracts by polyacrylamide gel electrophoresis and avoids the need to expose RNA to ribonucleases in order to obtain the ribonuclease-resistant poly(A) core. The effect of ageing of Physarum poly(A)+ mRNA on its translation was also examined.

\section{METHODS}

Materials. The Colonia Leicester (CL) strain of Physarum polycephalum was used in this study. Poly(U)-Sepharose was from Pharmacia, [2- ${ }^{3} \mathrm{H}$ ]adenosine $\left(24 \mathrm{Ci} \mathrm{mmol}^{-1}, 890 \mathrm{GBq} \mathrm{mmol}^{-1}\right)$ and $\mathrm{L}-\left[4,5-{ }^{3} \mathrm{H}\right]$ -

$\dagger$ Present address: Brewing Research Foundation, Lyttel Hall, Nutfield, Surrey RH1 4HY. 
leucine $\left(52 \mathrm{Ci} \mathrm{mmol}^{-1}, 1.92 \mathrm{TBq} \mathrm{mmol}{ }^{-1}\right)$ from The Radiochemical Centre, Amersham, pancreatic ribonuclease A $\left\{3.23 \times 10^{3}\right.$ units $\left.(\mathrm{mg} \text { protein })^{-1}\right\rceil$ and ribonuclease $\mathrm{T} 1\left[4.24 \times 10^{5}\right.$ units $\left.(\mathrm{mg} \text { protein })^{-1}\right\}$ from Worthington Biochemical Corp., Escherichia coli 5S RNA and yeast tRNA ${ }^{\text {Phe }}$ from Boehringer, creatine phosphokinase (110 units $\mathrm{mg}^{-1}$ ) and polyvinyl sulphate from Sigma, and fungal proteinase K from BDH. Freshly-ground wheat germ was a generous gift from W. P. H. Marriage and Sons, Chelmsford, Essex.

$\operatorname{Poly}(A)+m R N A$. Polysomal and post-polysomal fractions were isolated from exponentially gawing Physarum microplasmodia by procedures adapted from those of Brewer (1972), as described previously (Brown \& Hardman, 1980). Growth medium for microplasmodia was that described previously (Dee \& Poulter, 1970). Proteinase K digestion of the fractions, phenol/chloroform/isoamyl alcohol extraction, followed by poly(U)-Sepharose affinity chromatography were performed as described previously (Brown \& Hardman, 1980).

Poly $(A)$ tracts. Polysomal poly (A)+ mRNA $(50 \mu \mathrm{g})$ was digested at $37^{\circ} \mathrm{C}$ in $1.2 \mathrm{ml}$ of solution containing pancreatic RNAase A $\left(2.5\right.$ units $\left.\mathrm{ml}^{-1}\right)$, RNAase Tl (25 units $\left.\mathrm{ml}^{-1}\right), 10 \mathrm{~mm}$-EDTA, $0.2 \mathrm{M}-\mathrm{NaCl}, 10 \mathrm{mM}-$ Tris/ $\mathrm{HCl}, \mathrm{pH} 7 \cdot 5$. Portions of the reaction mixture $(10 \mu \mathrm{l})$ were withdrawn periodically to determine the amount of radioactivity rendered soluble in $5 \%(\mathrm{w} / \mathrm{v})$ trichloroacetic acid. After $30 \mathrm{~min}, 1.0 \mathrm{ml}$ of the reaction mixture was applied directly to a $0.3 \mathrm{~g}$ oligo(dT)-cellulose column, previously washed with $5 \mathrm{ml} 0.1 \%$ (v/v) diethyl pyrocarbonate, and equilibrated prior to use by washing with $5 \mathrm{ml} 0.5 \mathrm{M}-\mathrm{NaCl}, 10 \mathrm{mM}-\mathrm{Tris} / \mathrm{HCl}, \mathrm{pH} 7.5$ (buffer A). Unbound material was washed from the column using $5 \times 1.0 \mathrm{ml}$ portions of buffer A, and the bound fraction was eluted using $5 \times 1 \mathrm{ml}$ washes of $10 \mathrm{mM}$-Tris/ $\mathrm{HCl}, \mathrm{pH} 7.5$ (buffer B). Fractions of the eluate $(10 \mu$ l) were used to determine the amount of radioactivity precipitated in the presence of $5 \%(\mathrm{w} / \mathrm{v})$ trichloroacetic acid. Those fractions containing $\left[{ }^{3} \mathrm{H}\right]$ RNA bound to the column in the presence of buffer A were pooled and precipitated using 2 vol. $95 \%(\mathrm{v} / \mathrm{v})$ ethanol in the presence of $100 \mu \mathrm{g}$ calf thymus DNA carrier.

Gel electrophoresis. Poly(A)-containing RNAase-resistant material obtained from polysomal poly(A)+ mRNA was dissolved in $30 \mathrm{~mm}$-sodium phosphate, $1 \mathrm{mM}$-EDTA, $36 \mathrm{mM}$-Tris/ $\mathrm{HCl}$, pH 7.5, and electrophoresed for $9 \mathrm{~h}$ at $80 \mathrm{~V}(60 \mathrm{~mA})$ on a $10 \%(\mathrm{w} / \mathrm{v})$ polyacrylamide slab gel (Laemmli \& Favre, 1973; Loening, 1969). Oligo(dT) ${ }_{10}, E$. coli SS RNA and yeast tRNA ${ }^{\text {Phe }}$ were used as size standards. RNA samples were denatured before use by heating to $60^{\circ} \mathrm{C}$ for $2 \mathrm{~min}$ immediately before application to the gel. After electrophoresis the position of markers was determined by staining with acridine orange (McMaster \& Carmichael, 1977). $\left[{ }^{3} \mathrm{H}\right] \mathrm{RNA}$ was located by measuring the radioactive content of gel slices (Adamson \& Woodland, 1977). Gel slices (1.5 mm) were solubilized using $0.5 \mathrm{ml} 2 \%(\mathrm{v} / \mathrm{v}) 0.880 \mathrm{sp}$.gr. ammonia in $30 \%(\mathrm{v} / \mathrm{v}) \mathrm{H}_{2} \mathrm{O}_{2}$ for $48 \mathrm{~h}$ at $37{ }^{\circ} \mathrm{C}$.

Thermal elution from poly $(U)$-Sepharose. The methods used were adapted from those described by Palatnik et al. (1979). RNA samples were dissolved in $1.0 \mathrm{ml} 1 \%(\mathrm{w} / \mathrm{v})$ sodium dodecyl sulphate, $30 \mathrm{mM}$-EDTA, $50 \mathrm{mM}$-Tris $/ \mathrm{HCl}$, pH $8 \cdot 0$, heated to $60^{\circ} \mathrm{C}$ for $3 \mathrm{~min}$, cooled in solid $\mathrm{CO}_{2} /$ ethanol and re-equilibrated to $20^{\circ} \mathrm{C}$. Samples were then diluted fivefold with $20 \%(\mathrm{v} / \mathrm{v})$ formamide, $0.7 \mathrm{M}-\mathrm{NaCl}, 10 \mathrm{~mm}$-EDTA, $100 \mu \mathrm{g}$ polyvinyl sulphate (PVS) $\mathrm{ml}^{-1}, 30 \mathrm{mM}$-Tris/ $\mathrm{HCl}, \mathrm{pH} 7.5$ (buffer $\mathrm{C}$ ) and loaded on to $2 \mathrm{ml}$ poly(U)-Sepharose columns, previously equilibrated at $20^{\circ} \mathrm{C}$ with buffer $\mathrm{C}$. Poly(A)- RNA was eluted from the columns at $20^{\circ} \mathrm{C}$ with $10 \times$ $1.0 \mathrm{ml}$ fractions of buffer $\mathrm{C}$ and $10 \times 1.0 \mathrm{ml}$ fractions of $20 \%(\mathrm{v} / \mathrm{v})$ formamide, $0.1 \mathrm{M}-\mathrm{NaCl}, 10 \mathrm{mM}-\mathrm{EDTA}$, $100 \mu \mathrm{g} \mathrm{PVS} \mathrm{ml} \mathrm{m}^{-1}, 50 \mathrm{~mm}$-Tris/ $\mathrm{HCl}, \mathrm{pH} 7.5$ (buffer D). The temperature of the columns was raised from 20 to $84^{\circ} \mathrm{C}$ in $2{ }^{\circ} \mathrm{C}$ increments. At each temperature $3 \times 1.0 \mathrm{ml}$ volumes of buffer $\mathrm{D}$ were passed through the columns and the ${ }^{3} \mathrm{H}$ radioactivity was monitored.

Protein synthesis in vitro. The method used was that described by Marcu \& Dudock (1974) as modified by M. Cannon (personal communication). Viable embryos $(20 \mathrm{~g}$ ) were selected from the crude wheat germ by flotation on $\mathrm{CCl}_{4} /$ cyclohexane $(2 \cdot 5: 1, \mathrm{v} / \mathrm{v})$. These were ground whilst dry for $60 \mathrm{~s}$ at $4{ }^{\circ} \mathrm{C}$ with an equal weight of washed sand. After mixing with $40 \mathrm{ml} 100 \mathrm{~mm}$-potassium acetate, $1 \mathrm{~mm}$-magnesium acetate, $2 \mathrm{~mm}-\mathrm{CaCl}_{2}, 1 \mathrm{~mm}-$ dithiothreitol, $20 \mathrm{~mm}$-4-(2-hydroxyethyl)-1-piperazine-ethanesulphonic acid (HEPES), pH 7.4, the slurry was centrifuged at $30000 \mathrm{~g}$ for $15 \mathrm{~min}$ at $4^{\circ} \mathrm{C}$. The supernatant was applied to a Sephadex G-25 column $(15 \times$ $1.6 \mathrm{~cm}$ ) previously equilibrated with $120 \mathrm{~mm}$-potassium acetate, $5 \mathrm{~mm}$-magnesium acetate, $1 \mathrm{~mm}$-dithiothreitol, 20 mM-HEPES, pH 7.4 (buffer E). The samples were eluted using buffer E. The first 8 ml eluate after the void volume of the column was collected and centrifuged at $30000 \mathrm{~g}$ for $10 \mathrm{~min}$. The supernatant was stored at $-70^{\circ} \mathrm{C}$ under nitrogen.

The rate of in vitro protein synthesis was determined in $50 \mu \mathrm{l}$ reaction mixtures containing 20 mM-HEPES, pH 7.4, 2 mM-magnesium acetate, $130 \mathrm{~mm}$-potassium acetate, $2 \mathrm{~mm}$-dithiothreitol, $1 \mathrm{mM}$-ATP, $0.25 \mathrm{~mm}$-GTP, $8 \mathrm{mM}$ of each of the $20 \mathrm{~L}$-amino acids other than leucine, $2.5 \mu \mathrm{Ci} \mathrm{L}-\left[{ }^{3} \mathrm{H}\right]$ leucine, $1 \mu \mathrm{g}$ RNA template and $20 \mu 1$ wheat germ extract.

\section{RESULTS AND DISCUSSION}

\section{Properties of poly $(A)$ segments derived from poly $(A)+R N A$}

An exponentially growing culture of microplasmodia was labelled for $2.5 \mathrm{~h}$ in the presence of $5 \mu \mathrm{Ci}\left[{ }^{3} \mathrm{H}\right]$ adenosine $\mathrm{ml}^{-1}$. The organism was harvested and polysomal poly(A)+ mRNA 

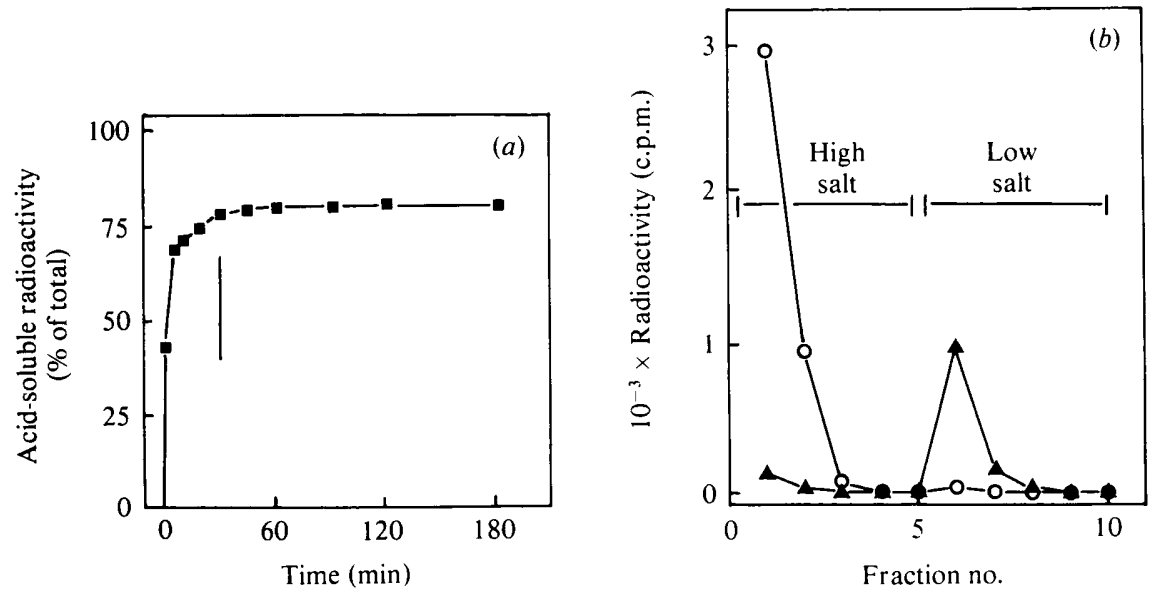

Fig. 1. Isolation of poly(A) segments from Physarum poly(A)+ RNA. (a) Time course of digestion of polysomal poly(A)+ mRNA (50 $\mu \mathrm{g})$ using 2.5 units RNAase $\mathrm{A} \mathrm{ml}^{-1}$ and 25 units RNAase T1 $\mathrm{ml}^{-1}$. The vertical bar indicates the point at which samples were taken for the analysis of poly(A) segment length. (b) Oligo(dT)-cellulose chromatography of RNAase-resistant material derived from polysomal poly(A)+ mRNA after 30 min digestion with RNAase A and RNAase $\mathrm{T} 1$, as shown in $(a)$. O, Acid-soluble ${ }^{3} \mathrm{H}$ radioactivity; $\boldsymbol{\Delta}$, acid-precipitable radioactivity.

was isolated. Samples (50 $\mu \mathrm{g})$ of the RNA were subjected to digestion using RNAase A and RNAase T1. Preliminary experiments were performed to determine the optimum conditions for digestion (results not shown) since it was known that RNAase A degrades poly(A) tracts slowly (Beers, 1960). The conditions finally employed were such that the minimum amounts of ribonuclease were added to digest the RNA completely in $30 \mathrm{~min}$ (Fig. 1a), thus minimizing the 'nibbling' effect of the enzymes on the $20 \%$ of the RNA which was resistant to the action of the enzymes, and presumed to represent the poly(A) core. Analysis of the digestion products using oligo(dT)-cellulose affinity chromatography revealed that $85 \%$ of the ${ }^{3} \mathrm{H}$ radioactivity that was acid-precipitable remained bound to the column, whereas $99 \%$ of the soluble radioactivity was eluted in the presence of $0.5 \mathrm{M}-\mathrm{NaCl}$ (Fig. $1 b$ ), thus confirming the nature of the RNAase-resistant material. The size distribution of the poly(A)-containing core material was determined by polyacrylamide gel electrophoresis with reference to $E$. coli 5S RNA (120 nucleotides; Brownlee et al., 1967), yeast tRNA ${ }^{\text {Phe }}$ (76 nucleotides; Rich \& Bhandary, 1976) and oligo(dT) $)_{10}$. Difficulties that were encountered when $10 \%$ polyacrylamide gels were sliced leave the possibility that the minor peaks and troughs of radioactivity on the gels (Fig. 2) were artefactual. However, it was clear that the distribution of lengths for the poly(A) segments in poly(A)+ mRNA was in the range 140 to 220 nucleotides.

These results are consistent with those of Fouquet et al. (1974), but disagree with the average length of 65 nucleotides reported by Adams \& Jeffery (1978). The reason for these discrepancies is not known, though it is likely to reside in differences in the conditions of digestion with ribonucleases. The average length of the poly(A) tract in Physarum poly(A)+ RNA found here is similar to those reported for mammalian-cell poly(A)+ RNA (Edmonds \& Caramela, 1969; Edmonds et al., 1971; Greenberg \& Perry, 1972; Mendecki et al., 1972), that is, approximately 200 nucleotides. In contrast, lengths of poly(A) segments ranging between 50 and 100 nucleotide residues have been reported in a variety of lower eukaryotic organisms, including Dictyostelium discoideum (Firtel et al., 1972), Saccharomyces (Groner et al., 1974), Blastocladiella emersonii (Jaworski, 1976) and Naegleria gruberi (Hickey et al., 1979). 


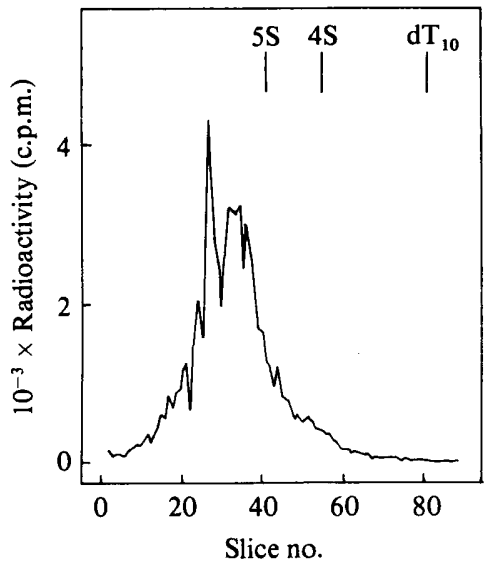

Fig. 2

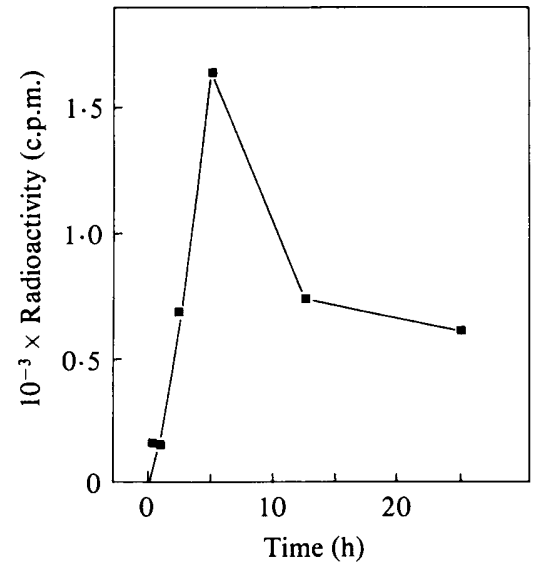

Fig. 3

Fig. 2. Polyacrylamide gel electrophoresis of poly(A) tracts derived from Physarum polysomal poly(A)+ mRNA. Poly(A) segments were isolated and electrophoresed on a $10 \%$ polyacrylamide slab gel (see Methods). The radioactive content of the gel slices is shown with reference to coelectrophoresed $E$. coli $5 S$ RNA, yeast tRNA ${ }^{\text {Phe }}(4 \mathrm{~S})$ and oligo $(\mathrm{dT})_{10}$ as size standards. The position of migration of standard RNA species was determined by staining the gel.

Fig. 3. Time course of incorporation of $\left[{ }^{3} \mathrm{H}\right]$ adenosine into Physarum poly $(\mathbf{A})+$ RNA. The incorporation of $\left[{ }^{3} \mathrm{H}\right.$ ladenosine $\left.(20 \mu \mathrm{Ci} \mathrm{ml})^{-1}\right)$ into poly $(A)+$ RNA during exponential growth of microplasmodia was followed. Experimental details are given in the text.

\section{Length of the poly $(A)$ tract and $m R N A$ age}

Adams \& Jeffery (1978) reported that the length of the poly(A) tract of Physarum mRNA decreases in parallel with the age of the message. Since the results obtained here, concerning the average length of poly(A) segments, were in conflict with this previous study, experiments were performed to investigate the shortening of poly(A) segments in more detail.

Comparison of mRNA populations that differ with respect to age is dependent on the kinetics of incorporation of radioactive substrate into mRNA. $\left[{ }^{3} \mathrm{H}\right]$ Adenosine was added to an exponentially growing culture of microplasmodia to a final concentration of $20 \mu \mathrm{Ci} \mathrm{ml} \mathrm{m}^{-1}$ and portions of the culture were analysed for acid-insoluble radioactivity. Microplasmodia were harvested and resuspended in $2 \%(\mathrm{w} / \mathrm{v})$ sodium citrate, $0.5 \%(\mathrm{w} / \mathrm{v})$ Triton X-100 (Ouellette et al., 1976) and homogenized at $4{ }^{\circ} \mathrm{C}$ using a Dounce ball-type homogenizer. Post-mitochondrial supernatants were obtained by centrifugation of homogenates at $10000 \mathrm{~g}$ for $10 \mathrm{~min}$ at $4{ }^{\circ} \mathrm{C}$. The supernatants were then made $75 \mathrm{~mm}$ with respect to $\mathrm{MgCl}_{2}$, incubated at $4^{\circ} \mathrm{C}$ for $45 \mathrm{~min}$, and precipitated ribonucleoprotein (Iwabuchi et al., 1970; Akalehiywot et al., 1977) was harvested by centrifugation at $10000 \mathrm{~g}$ for $10 \mathrm{~min}$ at $4{ }^{\circ} \mathrm{C}$. Control experiments showed that equal proportions of polysomal and monosomal ribonucleoproteins were precipitated using these procedures (results not shown). The incorporation of $\left[{ }^{3} \mathrm{H}\right]$ adenosine into poly $(\mathrm{A})+\mathrm{RNA}$ was measured by determining the radioactivity present in the poly(A)+ RNA fraction after purification using poly(U)Sepharose chromatography. The results (Fig. 3) indicated that $\left[{ }^{3} \mathrm{H}\right]$ adenosine was depleted after about $5 \mathrm{~h}$, after which the level of incorporated label decreased, probably due to turnover of the poly(A)+ mRNA. Hence, the use of 2.5 and $24 \mathrm{~h}$ labelling periods allowed analysis to be made of newly synthesized and relatively long-lived poly(A)+ mRNA, respectively.

The strength of the interaction between poly(U)-Sepharose and the poly(A) tract of mRNA is dependent on the length of the poly(A) segment (Palatnik et al., 1979). Hence, thermal elution chromatography using poly(U)-Sepharose can be used to reveal differences 

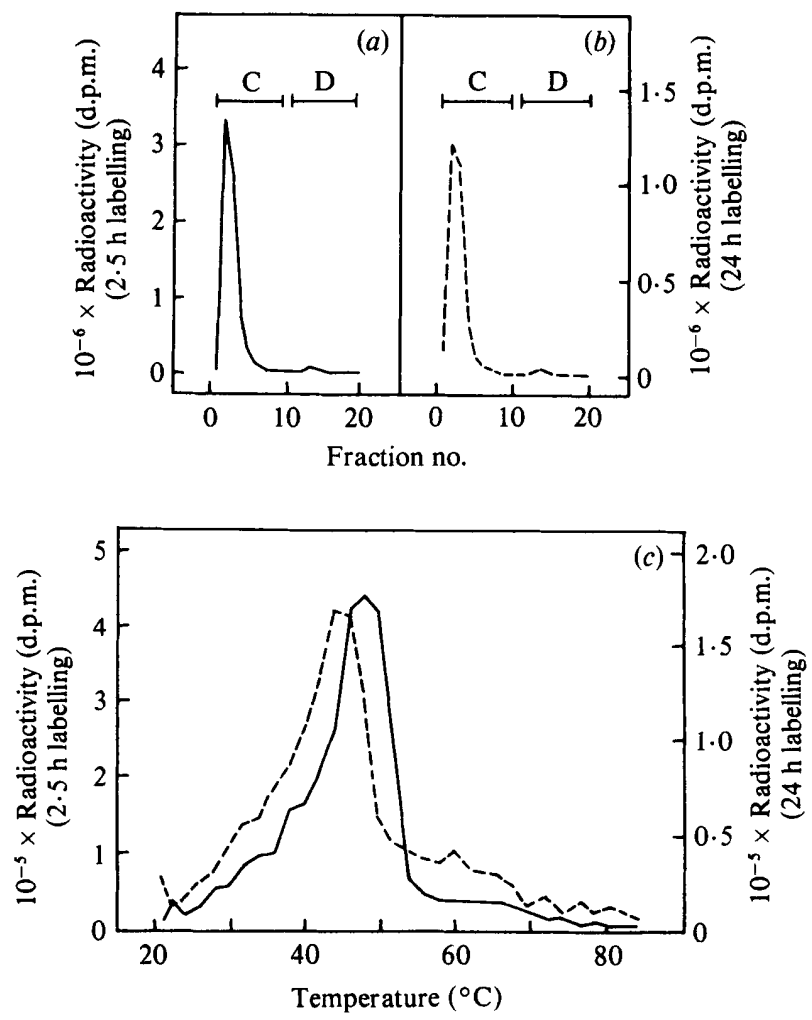

Fig. 4. Thermal elution chromatography of Physarum polysomal RNA using poly(U)-Sepharose. Polysomal RNA was isolated from exponentially growing microplasmodia after labelling for $2.5 \mathrm{~h}$ $(\longrightarrow)$ or $24 \mathrm{~h} \mathrm{(--)}$ with $20 \mu \mathrm{Ci}\left[{ }^{3} \mathrm{H}\right.$ ladenosine $\mathrm{ml}^{-1}$. RNA was subjected to thermal elution chromatography from poly(U)-Sepharose: $(a, b)$ elution profiles using buffer $\mathrm{C}$ and buffer $\mathrm{D}$ at $20^{\circ} \mathrm{C}$; (c) elution profiles of RNA using buffer $\mathrm{D}$ at increasing temperatures.

in the size of poly(A) tracts in different mRNA preparations. This technique was used here since it permits comparisons to be made between poly $(\mathrm{A})$ populations without recourse to the use of ribonuclease digestion, thus excluding the disadvantages in the application of the ribonuclease method.

Two polysomal RNA populations, isolated from exponentially growing cultures of microplasmodia labelled for 2.5 and $24 \mathrm{~h}$, respectively, with $20 \mu \mathrm{Ci}\left[{ }^{3} \mathrm{H}\right]$ adenosine $\mathrm{ml}^{-1}$, were subjected to thermal elution from poly(U)-Sepharose. The profiles of elution of the labelled RNA with increasing temperature (Fig. 4) showed that the major proportion of the long-labelled poly $(\mathrm{A})+\mathrm{mRNA}$ was released from the poly(U)-Sepharose column at a lower temperature than that labelled for $2.5 \mathrm{~h}$, indicating that the lengths of the poly(A) segments were shorter in most cases in longer-labelled mRNA. This confirms the observations of Adams \& Jeffery (1978) and is also consistent with the shortening of the poly(A) segment with mRNA age that has been observed previously in animal-cell poly (A) + mRNA (Sheiness et al., 1975; Wilson et al., 1978).

\section{Effect of $m R N A$ ageing on translation}

The efficiency of utilization of Physarum mRNA for translation was estimated by determining the proportion of the RNA that was present in actively translating polysome structures, as compared with monosomes (Harvey, 1973). The validity of this approach was 


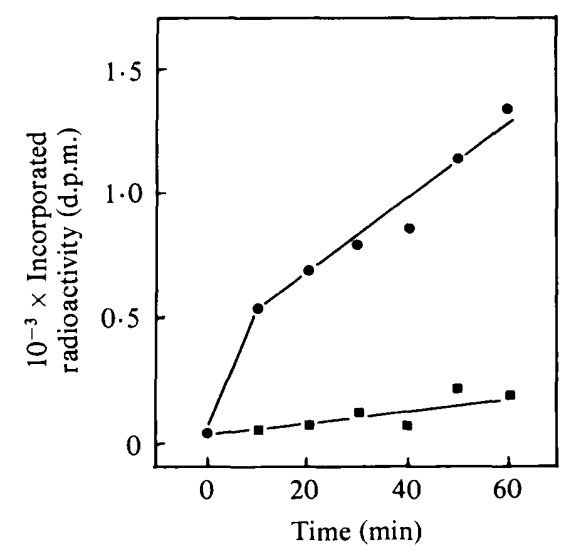

Fig. 5. Utilization of Physarum poly(A)+ RNA in a wheat germ protein-synthesizing system. Polysomal and post-polysomal poly $(\mathrm{A})+$ RNA were isolated from exponentially growing cultures of microplasmodia. Samples of each RNA preparation $(1 \mu \mathrm{g})$ were added to an in vitro proteinsynthesizing system prepared using wheat germ extract, and the rate of incorporation of $\mathrm{L}-\left[{ }^{3} \mathrm{H}\right]$ leucine into acid-insoluble material was monitored. O, Polysomal poly (A)+ RNA template; $\mathbf{n}$, post-polysomal poly(A)+ RNA template.

\section{Table 1. Effect of the age of poly $(A)+R N A$ on its utilization for translation}

Identical exponentially growing microplasmodial cultures were labelled for 2,12 and $24 \mathrm{~h}$, respectively, using $10 \mu \mathrm{Ci}\left[{ }^{3} \mathrm{H}\right.$ ]adenosine $\mathrm{ml}^{-1}$. Poly (A) + RNA was prepared, and the efficiency of utilization of the mRNA for translation was estimated by determining the ratio of $\left[{ }^{3} \mathrm{H}\right]$ poly $(\mathrm{A})+\mathrm{RNA}$ in polysomes to that in post-polysomal material.

\begin{tabular}{cc}
$\begin{array}{c}\text { Time of } \\
\text { labelling } \\
\text { (h) }\end{array}$ & Polysomal radioactivity \\
\cline { 2 - 2 } 2 & Post-polysomal radioactivity \\
12 & 7.6 \\
24 & 5.5 \\
& 2.9
\end{tabular}

assessed by comparing the relative template ability of Physarum polysomal and postpolysomal poly(A)+ mRNA using an in vitro wheat germ protein-synthesizing system. Polysomal or post-polysomal poly(A)+ RNA $(1 \mu \mathrm{g})$ was added to each assay mixture and portions $(6 \mu \mathrm{l})$ were taken over a period of $60 \mathrm{~min}$ to determine the extent of incorporation of L- $\left[{ }^{3} \mathrm{H}\right]$ leucine into acid-precipitable material. The results (Fig. 5) showed that polysomal poly(A)+ RNA is a more efficient template than monosomal poly(A)+ RNA under the conditions used and hence probably has a greater integrity and inherent functional capacity in vivo. It is conceivable, though unlikely, that selective degradation of post-polysomal poly(A)+ mRNA during isolation might also account for these observations. However, similar functional differences between polysomal and post-polysomal mRNA populations have been observed in other systems (Dworkin et al., 1977; Lee \& Engelhardt, 1979).

Three exponentially growing cultures of microplasmodia of identical culture density were labelled with $10 \mu \mathrm{Ci}\left[{ }^{3} \mathrm{H}\right]$ adenosine $\mathrm{ml}^{-1}$ for 2,12 and $24 \mathrm{~h}$ prior to harvesting. Poly (A)+ mRNA was isolated from polysomal and post-polysomal fractions and the ratio of ${ }^{3} \mathrm{H}$ radioactivity in polysomes to that in post-polysomal material was determined for each labelling period (Table 1). A reduction in this ratio was observed as the length of the labelling period increased. Electrophoretic analysis of the poly(A)+ RNA from polysomes and monosomes showed that the observation was not due to changes in the level of contamination 
of the poly (A)+ fractions with ribosomal RNA. Hence, the results suggest that the efficiency of utilization of mRNA for translation decreased as the age of the messenger RNA increased.

Such an observation is consistent with a previous report which described a reduction in the capacity of reticulocyte mRNA to support protein synthesis as the mRNA ages (Lodish \& Small, 1976). In contrast, the translational capacity of poly(A)+ mRNA for $\alpha$ - and $\beta$-globin, when injected into Xenopus laevis oocytes, does not decrease with time (Gurdon et al., 1973; Huez et al., 1974). The high stability of mRNA in the Xenopus laevis system may be responsible for some of the inconsistencies in the relationship between the age of an mRNA and its capacity for translation.

\section{Conclusions}

Three conclusions can be drawn from the data presented here. First, the length of the poly(A) tracts in Physarum poly(A)+ RNA is shown to range from 140 to 220 nucleotide residues, using experimental conditions which minimize the artefactual degradation of the poly(A) segment by ribonucleases. The conditions used here differ from those used previously (Fouquet et al., 1974; Adams \& Jeffery, 1978) in that we have employed milder treatments with RNAase and have determined the length of the poly(A) segments with reference to appropriate RNA standards of known chain size. Second, thermal elution chromatography from poly(U)-Sepharose has shown that the poly(A) segments become shorter as the population of mRNA molecules ages. Third, it has been possible to determine the efficiency with which mRNA populations in Physarum are utilized for translation by comparing the proportion of poly(A)+ RNA present in polysomes with that in monosomes. As the age of the poly(A)+ mRNA increases, its ability to be utilized for translation appears to decrease. This is probably related to the turnover of poly $(\mathrm{A})+$ RNA or some other in vivo phenomenon.

We are grateful to our colleagues, notably Roy Fergie and Dr W. T. Melvin, for helpful discussions during the early part of this work. A. J. P. B. is grateful to the Science Research Council for the award of a studentship. N. H. thanks the Medical Research Council and the Cancer Research Campaign for support, and Professor H. M. Keir for the provision of facilities in the Department of Biochemistry.

\section{REF ERENCES}

Adams, D. S. \& JefFery, W. R. (1978). Poly(adenylic acid) degradation by two distinct processes in the cytoplasmic RNA of Physarum polycephalum. Biochemistry 17, 4519-4524.

Adamson, E. D. \& Woodland, H. R. (1977). Changes in the rate of histone synthesis during oocyte maturation and very early development of Xenopus laevis. Developmental Biology 57, 136149.

Akalehiywot, T., Gedamu, L. \& Bewley, J. D. (1977). The isolation of polyribosomes from plant material using magnesium precipitation in the presence of heparin. Canadian Journal of Biochemistry 55, 901-904.

BEERS, R. F. (1960). Hydrolysis of polyadenylic acid by pancreatic ribonuclease. Journal of Biological Chemistry 235, 2393-2398.

Brewer, E. N. (1972). Polysome profiles, amino acid incorporation in vitro, and polysome reaggregation following disaggregation by heat shock during the mitotic cycle in Physarum polycephalum. Biochimica et biophysica acta 277, 639-645.

Brown, A. J. P. \& Hardman, N. (1980). Utilization of poly(A)+ messenger RNA during growth and starvation in Physarum polycephalum. European Journal of Biochemistry (in the Press).
Brownlee, G. G., Sanger, F. \& Barrell, B. G. (1967). Nucleotide sequence of 5S-ribosomal RNA from Escherichia coli. Nature, London 215, 735736.

DEE, J. (1975). Slime moulds in biological research. Science Progress 62, 523-542.

DeE, J. \& Poulter, R. T. M. (1970). Gene conferring actidione resistance and abnormal morphology on Physarum polycephalum plasmodia. Genetical $R \boldsymbol{e}$ search 15, 35-41.

Dworkin, M. B., Rudensey, L. M. \& Infante, A. A. (1977). Cytoplasmic non-polysomal ribonucleoprotein particles in sea urchin embryos and their relationship to protein synthesis. Proceedings of the National Academy of Sciences of the United States of America 74, 2231-2235.

Edmonds, M. \& Caramela, M. G. (1969). The isolation and characterisation of adenosine monophosphate-rich polynucleotides synthesised by Ehrlich ascites cells. Journal of Biological Chemistry 244, 1314-1324.

Edmonds, M., Vaughan, M. H. \& Nakazato, H. (1971). Polyadenylic acid sequences in the heterogeneous nuclear RNA and rapidly-labelled polyribosomal RNA of HeLa cells: possible evidence for a precursor relationship. Proceedings of the National 
Academy of Sciences of the United States of America 68, 1336-1340.

FirTel, R. A., Jacobson, A. \& Lodish, H. F. (1972). Isolation and hybridization kinetics of messenger RNA from Dictyostelium discoideum. Nature New Biology 239, 225-228.

Fouquet, H., Bohme, R., Wick, R., SAUER, H. W. \& BrAUN, R. (1974). Isolation of adenylate-rich RNA from Physarum polycephalum. Biochimica et biophysica acta 353, 313-322.

Greenberg, J. R. \& Perry, R. P. (1972). Isolation and characterization of steady-state-labelled messenger RNA from L-cells. Biochimica et biophysica acta 287, 361-366.

Groner, B., Hynes, N. \& Phillips, S. (1974). Length heterogeneity in the poly(adenylic acid) region of yeast messenger RNA. Biochemistry 13, 53785385.

Gurdon, J. B., Lingrel, J. B. \& MARBAIX, G. (1973). Message stability in injected frog oocytes: long life of mammalian $\alpha$ - and $\beta$-globin messages. Journal of Molecular Biology 80, 539-551.

HARVEY, R. J. (1973). Fraction of ribosomes synthesising protein as a function of specific growth rate. Journal of Bacteriology 114, 287-293.

Hickey, C., Nakazato, H., Edmonds, M. \& Walsh, C. (1979). Poly(A) sequences in Naegleria messenger RNA before and after initiation of differentiation. Experimental Cell Research 120, 277-284.

Huez, G., Marbaix, G., Hubert, E., Leclerce, M., Nudel, U., Soreq, H., Saloman, R., Lebau, B., Revel, M. \& LitTAuer, U. Z. (1974). Role of the polyadenylate segment in the translation of globin messenger RNA in Xenopus oocytes. Proceedings of the National Academy of Sciences of the United States of America 71, 3143-3146.

IWABUCHI, M., ITo, K. \& Ochal, H. (1970). Characterization of ribosomes in the cellular slime mould Dictyostelium discoideum. Journal of Biochemistry 68, 549-559.

JAWORSKI, A. J. (1976). Synthesis of polyadenylic acid RNA during zoospore differentiation and germination in Blastocladiella emersonii. Archives of Biochemistry and Biophysics 173, 201-209.

LAEMmLI, U. K. \& FAVRE, M. (1973). Maturation of the head of bacteriophage T4: DNA packaging events. Journal of Molecular Biology 80, 575-599.
Lee, G. T.-Y. \& Engelhardt, D. L. (1979). Peptide coding capacity of polysomal and non-polysomal messenger RNA during growth of animal cells. Journal of Molecular Biology 129, 221-233.

Lodish, H. F. \& SMALL, B. (1976). Different lifetimes of reticulocyte messenger RNA. Cell 7, 59-65.

LoENING, U. E. (1969). The determination of the molecular weight of ribonucleic acid by polyacrylamide gel electrophoresis: the effects of changes in conformation. Biochemical Journal 113, 131-138.

MCMAster, G. K. \& Carmichael, G. G. (1977). Analysis of single- and double-stranded nucleic acids on polyacrylamide and agarose gels by using glyoxal and acridine orange. Proceedings of the National Academy of Sciences of the United States of America 74, 4835-4838.

MARCU, K. \& DUDOCK, B. (1974). Characterisation of a highly efficient protein synthesising system derived from commercial wheat germ. Nucleic Acids Research 1, 1385-1397.

Mendecki, J., Lee, S. Y. \& Brawerman, G. (1972). Characteristics of the polyadenylic acid segment associated with messenger ribonucleic acid in mouse sarcoma 180 ascites cells. Biochemistry 11, 792798.

Ouellette, A. J., Bandman, E. \& Kumar, A. (1976). Regulation of ribosomal RNA methylation in a temperature sensitive mutant of BHK cells. Nature, London 262, 619-621.

Palatnik, C. M., Storti, R. V. \& Jacobson, A. (1979). Fractionation and functional analysis of newly synthesised and decaying messenger RNAs from vegetative cells of Dictyostelium discoideum. Journal of Molecular Biology 128, 371-395.

RICH, A. \& BHANDARY, U. L. R. (1976). Transfer RNA: molecular structure, sequence and properties. Annual Review of Biochemistry 45, 806-860.

Sheiness, D., PuCKet, L. \& Darnell, J. E. (1975). Possible relationship of poly(A) shortening to mRNA turnover. Proceedings of the National Academy of Sciences of the United States of America 72, 1077-1081.

Wilson, M. C., SaWacki, S. G., White, P. A. \& DARnell, J. E. (1978). A correlation between the rate of poly(A) shortening and half-life of messenger RNA in adenovirus-transformed cells. Journal of Molecular Biology 126, 23-36. 